\title{
PRODUCTION OF AUSTRALIAN CEDAR SEEDLINGS INOCULATED WITH ARBUSCULAR MYCORRHIZAL FUNGI IN DIFFERENT TYPES OF CONTAINERS ${ }^{1}$
}

\author{
Élida Ribeiro do Carmo ${ }^{2}$, Cristiane Figueira da Silva ${ }^{3 *}$, Marta Simone Mendonça Freitas ${ }^{4}$, Késsia Barrêto \\ Lima $^{2}$ and Marco Antonio Martins ${ }^{2}$
}

\footnotetext{
${ }^{1}$ Received on 09.07.2014 accepted for publication on 01.12.2015.

${ }^{2}$ Universidade Estadual do Norte Fluminense Darcy Ribeiro, Centro de Ciências e Tecnologias Agropecuárias, Campos dos Goytacazes, RJ - Brasil.E-mail: <elidacarmo@yahoo.com.br>, <kblima@hotmail.com> and <marco@uenf.br>.

${ }^{3}$ Universidade Federal Rural do Rio de Janeiro, Instituto de Agronomia, Seropédica, RJ - Brasil. E-mail: <cfigueirasilva@yahoo.com.br>.

${ }^{4}$ Universidade Estadual do Norte Fluminense Darcy Ribeiro, Laboratório de Fitotecnia, Campos dos Goytacazes, RJ - Brasil. E-mail:<msimone@uenf.br>.

${ }^{*}$ Corresponding author.
}

\begin{abstract}
The present study aimed to evaluate the growth and the levels of N, P, K, Ca and Mg in Australian cedar seedlings which had been inoculated with arbuscular mycorrhizal fungi (AMF) in different types of containers. The experiment was carried out in a greenhouse and the experimental design was that of randomized complete blocks (RCB), with a $4 \times 4$ factorial design consisting of four inoculation treatments with AMF (Rhizophagus clarum, Gigaspora margarita, a mixed inoculation ( R. clarum + G. margarita) and the control (with no AMF inoculation); four types of containers (plastic bags measuring $250 \mathrm{~cm}^{3}$, tubes of 55 and $130 \mathrm{~cm}^{3}$ and pressed blocks $440 \mathrm{~cm}^{3}$. plant ${ }^{-1}$ ), with four repetitions. The height, the diameter of the stem base, the aerial part dry weight (APDW), the dry weight of the root (DWR) and the total plant dry weight (DW) were measured, along with the Dickson quality index, the percentage of mycorrhizal colonization and the levels of $\mathrm{N}, \mathrm{P}, \mathrm{K}, \mathrm{Ca}$ and $\mathrm{Mg}$ in the aerial part dry weight. One hundred and thirty eight days (138) days after sowing, the greatest growth and/or the highest levels of P, K and Ca could be observed in the aerial part dry weight of the Australian cedar seedlings which had been planted in the pressed block container and inoculated with a mixture of the two AMF species $(G$. margarita $+R$. clarum) or with just $R$. clarum. Thus it can be seen that AMF can make a significant contribution to the production of Australian cedar seedlings.
\end{abstract}

Keywords: Toona ciliata; Tubes; Pressed blocks.

\section{PRODUÇÃO DE MUDAS DE CEDRO AUSTRALIANO INOCULADAS COM FUNGOS MICORRÍZICOS ARBUSCULARES EM DIFERENTES RECIPIENTES}

\begin{abstract}
RESUMO - O presente trabalho teve por objetivo avaliar o crescimento e os teores de $\mathrm{N}, \mathrm{P}, \mathrm{K}, \mathrm{Ca}$ e $\mathrm{Mg}$ em mudas de cedro australiano em resposta à inoculação com fungos micorrizicos arbusculares (FMAs), em diferentes tipos de recipientes. O experimento foi realizado em casa de vegetação e o delineamento experimental foi o de blocos inteiramente casualizados, com esquema fatorial de $4 \times 4$ sendo: quatro tratamentos de inoculação com FMAs (Rhizophagus clarum, Gigaspora margarita, inóculo misto (R. clarum $+\boldsymbol{G}$ margarita) e o controle (sem inoculação com FMAs); quatro tipos de recipientes (sacos plásticos de $250 \mathrm{~cm}^{3}$, tubetes de 55 e 130 $\mathrm{cm}^{3}$ e bloco prensado $440 \mathrm{~cm}^{3}$. planta-1), com quatro repetições. Foram avaliadas altura, diâmetro do colo, massa seca da parte aérea (MSPA), massa seca da raiz (MSR) e massa seca total (MST), indice de qualidade de Dickson, porcentagem de colonização micorrízica e teores de N, P, K, Ca e Mg na massa seca da parte aérea. Observou-se, aos 138 dias após a semeadura, maior crescimento elou maiores teores de P, Ke Ca
\end{abstract}


na massa seca da parte aérea das mudas de cedro australiano cultivadas no recipiente bloco prensado e inoculadas com a mistura de duas espécies de FMAs (G margarita + R. clarum) ou com R. clarum. Os FMAs podem contribuir significativamente para a produção de mudas de cedro australiano.

Palavras-chave: Toona ciliata; Tubetes; Blocos prensados.

\section{INTRODUCTION}

Australian cedar (Toona ciliata) is a species native to Australia which has found conditions favorable for its adaptation in Brazil, exhibiting rapid growth in suitable conditions (MURAKAMI, 2008). By virtue of its relatively short cycle, good productivity and the value of its wood on both the domestic and international market, this species is excelling in the sawn timber segment of the market (WAC, 2012). Its wood is similar to that of the species Cedrela odorata and Cedrela fissilis (PINHEIRO et al., 2003; MURAKAMI, 2008), which are native to Brazil, and it shows resistance to attacks by mahogany shoot borers (Hipsipyla grandella) (CUNNINGHAM et al., 2005).

Information about the methods and techniques for the production of Australian cedar seedlings is still at a very early stage (SOUZA et al., 2009; LISBOA et al., 2012; KALIL FILHO; WENDLING, 2012). It is known that different methods of cultivation used in the production of tree seedlings directly affect the morphophysical characteristics which are indicators of quality (FREITAS et al., 2010; AJALA et al., 2012; LISBOA et al., 2012). One of the most important aspects in the seedling production process is making the most suitable choice of container (KELLER et al., 2009). According to some authors (AJALA et al., 2012; LISBOA et al., 2012), this can promote benefits, such as better growth and development of the aerial parts and the root system and higher rates of survival for the seedlings planted out in the field, in addition to avoiding unnecessary expenditure on substrate.

Plastic bags have been used quite widely in this market, since they involve low levels of investment in infrastructure (ZANI FILHO, 1996). According to Souza et al. (2010) some nurseries produce Australian cedar seedlings in plastic bags, but, while these bags are even cheaper than tubes, they cannot be re-used, they involve the use of more labor, increase the cost of both substrate and transport as well as reducing the levels of efficiency of the planting operations (AJALA et al., 2012). In addition, this kind of container tends to lead to entanglement of the root system, which can impede the development of the seedlings planted out in the field (HAHN et al., 2006).

On the other hand, tubes make it more difficult for the root systems to become entangled, due to the presence of internal longitudinal grooves (CARNEIRO, 1995). However, the presence of a rigid wall imposes restrictions on root growth and can lead to stress and root deformation in some species after they have been planted out, with a reduction in the capacity of the plant to absorb water and nutrients from the soil and with slower rates of initial growth in the field (BARROSO et al., 2000a; FREITAS et al., 2005; KELLER et al., 2009).

In some Scandinavian countries, seedling production systems have used pressed blocks, made from organic residue (CARNEIRO, 1995; BARROSO et al., 2000b). Using pressed blocks in the production system has proved successful in allowing the root system to grow freely, without leading to structural deformations (FREITAS et al., 2005; KELLER et al., 2009; FREITAS et al., 2010). In addition, the process can be mechanized, in the same way as when using containers with rigid walls, maximizing productivity (FREITAS et al., 2005).

In addition to using containers most suitable for the seedlings' development, inoculation with arbuscular mycorrhizal fungi (AMF) can also make a significant contribution to the process of producing high-quality seedlings in tree nurseries (SCHIAVO; MARTINS, 2003; ROCHA et al., 2006). AMF are symbiont organisms which combine with plant roots and this can result in benefits, such as an increase in the strength of the seedlings and accelerated rates of growth, better use of nutrients, a reduction in the need for inputs and greater tolerance of stress during the process of transplanting out in the field. (CARNEIRO et al., 2004; ROCHA et al., 2006; ANGELINI et al., 2013; LIMA; SOUSA, 2014).

The aim of this study, therefore, was to assess growth and levels of $\mathrm{N}, \mathrm{P}, \mathrm{K}, \mathrm{Ca}$ and $\mathrm{Mg}$ in Australian cedar seedlings inoculated with AMF, in different types of containers. 


\section{MATERIALAND METHODS}

The experiment was carried out at the greenhouse belonging to the Universidade Estadual do Norte Fluminense Darcy Ribeiro (UENF), in Campos dos Goytacazes (RJ). The experiment design used was a randomized complete block design (RCB), with a $4 \times 4$ factorial scheme, consisting of: four AMF inoculation treatments (Rhizophagus clarum, Gigaspora margarita), a mixed inoculation ( $G$. margarita $+R$. clarum); and the control (with no AMF inoculation); four types of containers (plastic bags of $250 \mathrm{~cm}^{3}$, tubes of 55 and $130 \mathrm{~cm}^{3}$ and pressed blocks of $440 \mathrm{~cm}^{3} /$ plant), with four repetitions. Each repetition consisted of 12 plants, bringing the total for each treatment to one pressed block with 54 seedlings, one tray with 48 tubes of $55 \mathrm{~cm}^{3}$, one tray with 48 tubes of $130 \mathrm{~cm}^{3}$ and 48 plastic bags.

The substrate used for the production of the seedlings was composed of a mixture of coconut fiber $(40 \%)$, pine bark (20\%) and vermiculite (40\%), with the following chemical characteristics: $\mathrm{N}=7.0 \mathrm{~g} \mathrm{dm}^{-3}$; $\mathrm{P}=1.7 \mathrm{~g} \mathrm{dm}^{-3} ; \mathrm{K}=1.6 \mathrm{~g} \mathrm{dm}^{-3} ; \mathrm{Ca}=4.6 \mathrm{~g} \mathrm{dm}^{-3} ; \mathrm{Mg}$ $=12 \mathrm{~g} \mathrm{dm}^{-3} ; \mathrm{S}=1.6 \mathrm{~g} \mathrm{dm}^{-3} ; \mathrm{Fe}=9996 \mathrm{mg} \mathrm{dm}^{-3} ; \mathrm{Cu}=$ $12 \mathrm{mg} / \mathrm{dm}^{3} ; \mathrm{Zn}=40 \mathrm{mg} / \mathrm{dm}^{3} ; \mathrm{Mn}=192 \mathrm{mg} / \mathrm{dm}^{3}$. The pressed blocks were made from a mixture of substrate, glue and polymer. These were laid out in a metal mold $60 \times 40 \times 10 \mathrm{~cm}$ (length, width and height). The material was pressed at $10 \mathrm{kgf} \mathrm{cm}^{-2}$, for 15 minutes, for its agglomeration. After the pressing had taken place, the blocks were transferred to a wooden box with cages funds of the same length and width.

The seeds of Australian cedar were acquired from the company Caiçara Comércio de Sementes Ltda, located in Brejo Alegre, in the state of Sao Paulo. The seeding was carried out in August 2011 and three seeds (not sterilized) were placed in each container, which had been correctly filled with substrate. In the pressed block, 54 seeding points were made, correctly spaced out. Thirty days after seeding, the seedlings were thinned out, leaving just one plant, the one which was strongest and most centrally positioned in the container. During the course of the experiment, four applications of nitrogen were given ( $10 \mathrm{mg} \mathrm{dm}^{-3}$ in ammonium nitrate form) to all the treatments.

The AMF species (R. clarum and G. margarita) came from the germplasm bank at the Soil Laboratory of the UENF Microbiology Department (Laboratório de Solos - Setor de Microbiologia), and these were multiplied in Zea mays L. seeds (CARMO, 2012).

After 138 days, the evaluations of the biometric characteristics were carried out (plant height and stem base width) and the Australian cedar seedlings were collected (aerial parts and roots), selecting three plants from each repetition. The aerial part and the root were dried in a forced ventilation stove, and then weighed, thus obtaining the aerial part dry weight (APDW), the dry weight of the root (DWR) and the total dry weight (DW). Based on the morphological characteristics, the Dickson quality index was calculated (DQI): $\mathrm{DQI}=[(\mathrm{DW})$ / (H/ND) + (APDW/DWR)]. In which: DW = total dry weight $(\mathrm{g}) ; \mathrm{H}=$ height of the aerial part $(\mathrm{cm}) ; \mathrm{ND}=$ stem base diameter $(\mathrm{mm})$; APDW $=$ aerial part dry weight $(\mathrm{g}) ; \mathrm{DWR}=$ dry weight of root $(\mathrm{g})$.

In order to determine the $\mathrm{N}, \mathrm{P}, \mathrm{K}, \mathrm{Ca}$ and $\mathrm{Mg}$ content in the aerial part dry weight, 12 plants were selected from each of the treatments. These samples were ground in a Wiley microgrinder with a 20 mesh. The plant material was oxidized by sulphuric digestion, and the extract from which the nitrogen content could be measured was obtained using the Nessler method (JACKSON, 1965), the phosphorus content was measured by the molybdate colorimetric test and the potassium content measured through flame emission spectrophotometry. The calcium and the magnesium levels were measured by atomic absorption spectrophotometry. (MALAVOLTA et al., 1997).

For the determination of the mycorrhizal colonization percentage, approximately $1 \mathrm{~g}$ of very fine roots was used, in accordance with the methodology described by Grace and Stribley (1991) with adaptations (CARMO, 2012). The roots (the presence of AMF structures) were evaluated with an optical microscope, following the procedures described by Giovanetti and Mosse (1980).

The data were subjected to variance analyses, using the SANEST program (ZONTA et al., 1984), and the averages compared using the Tukey test at 5\% probability.

\section{RESULTS}

The effects of the interaction between the kind of container used and the arbuscular mycorrhizal fungi (AMF) were confirmed in relation to all the variables analyzed in the present study, except for the $\mathrm{N}$ and $\mathrm{Mg}$ levels in the aerial part (Table 1).

Revista Árvore, Viçosa-MG, v.40, n.2, p.269-278, 2016

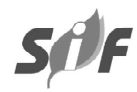


Table 1 - Analysis of variations in height, stem base diameter, aerial part dry matter (APDW), dry weight of root (DWR) and total dry weight (DW), Dickson Quality Index (DQI), mycorrhizal colonization and levels of nutrients (N, $\mathrm{P}, \mathrm{K}, \mathrm{Ca}$ and $\mathrm{Mg}$ ) in Australian cedar seedlings, 138 days after sowing, inoculated with AMF in different types of containers.

Tabela 1 - Análise de variância da altura, diâmetro do colo, massa seca da parte aérea (APDW), raízes (DWR) e total $(D W)$, indice de qualidade de Dickson (DQI), colonização micorrízica e teores nutricionais (N, $P, K, C a$ e $M g)$ das mudas de cedro australiano, 138 dias após a semeadura, inoculadas com FMAs em diferentes recipientes.

\begin{tabular}{|c|c|c|c|c|c|c|c|}
\hline \multirow[t]{3}{*}{ Variation Causes } & & \multicolumn{6}{|c|}{ Containers } \\
\hline & & Height & Diameter & DWR & APDW & DW & DQI \\
\hline & DF & \multicolumn{6}{|c|}{ AS } \\
\hline Fungi & 3 & $52.63 *$ & $1.70 *$ & $0.06^{*}$ & $0.65 *$ & $1.06 *$ & $0.01 *$ \\
\hline Containers & 3 & $218.78 *$ & $13.18 *$ & $0.60 *$ & $3.08 *$ & $6.38 *$ & $0.18 *$ \\
\hline $\mathrm{F} \times \mathrm{R}$ & 9 & $17.60 *$ & $0.43 *$ & $0.03 *$ & $0.41 *$ & $0.61 *$ & $0.01 *$ \\
\hline \multirow[t]{3}{*}{ Residue } & 48 & 0.51 & 0.02 & 0.00 & 0.00 & 0.01 & 0.00 \\
\hline & & Colonization & $\mathrm{N}$ & $\mathrm{P}$ & $\mathrm{K}$ & $\mathrm{Ca}$ & $\mathrm{Mg}$ \\
\hline & DF & \multicolumn{6}{|c|}{ AS } \\
\hline Fungi & 3 & $8060.42 *$ & $2.21 *$ & $1.45^{*}$ & $28.44 *$ & $1.00 *$ & 0.36 \\
\hline Containers & 3 & $789.58 *$ & $64.11 *$ & $8.49 *$ & $293.51 *$ & $13.70 *$ & 1.10 \\
\hline F x R & 9 & $432.61 *$ & 1.07 & $0.34 *$ & $3.68 *$ & $1.31 *$ & 0.87 \\
\hline Residue & 48 & 126.04 & 0.52 & 0.05 & 1.64 & 0.27 & 0.43 \\
\hline
\end{tabular}

$\mathrm{DF}=$ Degree of Freedom; AS = Average Square

Australian cedar seedlings grown in pressed blocks and inoculated with $R$. clarum or with the mixed inoculate (G. margarita $+R$. clarum), showed, 138 days after seeding, the biggest increases in height and stem base diameter. With regard to the dry weight of root (DWR), the aerial part dry weight (APDW) the total dry weight (DW) and the Dickson quality index (DQI), the seedlings which showed the greatest increases were those planted in pressed blocks and inoculated with $R$. clarum (Table 2).

With regard to the levels of nutrients in the aerial parts of the seedlings, the type of container and the inoculation with AMF had no significant effect on the levels of $\mathrm{Mg}$ in the aerial part of the plant (Table 3). However, regarding levels of $\mathrm{N}$, it was found that seedlings planted in either pressed blocks or plastic bags, independently of whether they had been inoculated with AMF or not, as well as those inoculated with the mixed AMF inoculate, independently of which type of container was used, had higher levels of $\mathrm{N}$ than those planted in the tubes of either 55 or $130 \mathrm{~cm}^{3}$ (Table 3 ). In addition, signs of $\mathrm{N}$ deficiency (older leaves with a pale green color, becoming dark yellow together with a lower rate of plant growth) were observed in the seedlings grown in the tubes $\left(55\right.$ and $\left.130 \mathrm{~cm}^{3}\right)$. With regard to the other nutrients ( $\mathrm{P}, \mathrm{K}$ and $\mathrm{Ca}$ ), in general, the highest averages were found in the seedlings grown in the pressed block containers which had been inoculated with the AMF mixed inoculate (Table 3 ).

When the rate of mycorrhizal colonization of the seedlings' roots was measured, 138 days after planting, it was found to be significantly higher in the treatments which had been inoculated with AMF then in the ones without AMF inoculation (the controls) and this was true for all types of containers (Table 4).

\section{DISCUSSION}

Use of the pressed block container, in combination with the inoculation of the seedlings using the species $R$. clarum or the mixed inoculant, led to the best development of the Australian cedar, 138 days after planting. Some authors (SCHIAVO; MARTINS, 2003; FREITAS et al., 2006; KELLER et al., 2009) have reported a greater increase in height and/or diameter, in various different species of trees, when they were planted in pressed blocks. According to Daniel et al. (1997) and Carneiro (1995), stem base diameter is the best measurement to use when evaluating the seedling's capacity to survive in the field. Based on this premise, it can be stated that the Australian cedar seedlings sown in pressed blocks and inoculated with $R$. clarum or the mixed inoculant have the greatest probability of surviving in the field, since these have the largest stem base diameters. 
Table 2 - Height, stem base diameter, dry weight of root (DWR), aerial part (APDW) and total (DW) and the Dickson Quality Index (DQI) in Australian cedar seedlings (Toona ciliata), inoculated or not with AMF, in different types of containers, 138 days after sowing.

Tabela 2 - Altura, diâmetro do colo, matéria seca de raiz (DWR), parte aérea $(A P D W)$ e total (DW) e indice de qualidade de Dickson (DQI) de mudas de cedro australiano (Toona ciliata), inoculados ou não com FMAs, em diferentes recipientes, 138 dias após a semeadura.

\begin{tabular}{|c|c|c|c|c|}
\hline \multirow[t]{3}{*}{ AMF inoculation } & \multicolumn{4}{|c|}{ Containers } \\
\hline & Tube $130 \mathrm{~cm}^{3}$ & Tube $55 \mathrm{~cm}^{3}$ & Plastic Bag & Pressed Block \\
\hline & \multicolumn{4}{|c|}{ Height $(\mathrm{cm})$} \\
\hline Control & $4.93 \mathrm{Aab}$ & $4.40 \mathrm{Ab}$ & $5.10 \mathrm{Cab}$ & $6.28 \mathrm{Ca}$ \\
\hline Rhizophagus clarum & $5.48 \mathrm{Ac}$ & $5.03 \mathrm{Ac}$ & $8.96 \mathrm{Ab}$ & $16.62 \mathrm{Aa}$ \\
\hline Gigaspora margarita & $5.62 \mathrm{Abc}$ & $4.33 \mathrm{Ac}$ & $6.84 \mathrm{Bb}$ & $12.67 \mathrm{Ba}$ \\
\hline Mixed & $6.05 \mathrm{Ac}$ & $4.86 \mathrm{Ac}$ & $9.04 \mathrm{Ab}$ & $16.0 \mathrm{Aa}$ \\
\hline \multicolumn{5}{|c|}{ Stem base diameter $(\mathrm{mm})$} \\
\hline Control & $1.88 \mathrm{Bb}$ & $1.89 \mathrm{Ab}$ & $1.98 \mathrm{Cb}$ & $2.91 \mathrm{Ca}$ \\
\hline Rhizophagus clarum & $2.24 \mathrm{Ac}$ & $1.86 \mathrm{Ad}$ & $3.04 \mathrm{Ab}$ & $4.47 \mathrm{Aa}$ \\
\hline Gigaspora margarita & $2.23 \mathrm{Ab}$ & $1.73 \mathrm{Ac}$ & $2.38 \mathrm{Bb}$ & $3.91 \mathrm{Ba}$ \\
\hline Mixed & $2.26 \mathrm{Ac}$ & $1.78 \mathrm{Ad}$ & $2.90 \mathrm{Ab}$ & $4.25 \mathrm{Aa}$ \\
\hline \multicolumn{5}{|c|}{$\operatorname{DWR}(\mathrm{g})$} \\
\hline Control & $0.131 \mathrm{Ab}$ & $0.076 \mathrm{Ac}$ & $0.114 \mathrm{Bb}$ & $0.304 \mathrm{Ca}$ \\
\hline Rhizophagus clarum & $0.157 \mathrm{Abc}$ & $0.076 \mathrm{Ac}$ & $0.248 \mathrm{Ab}$ & $0.700 \mathrm{Aa}$ \\
\hline Gigaspora margarita & $0.173 \mathrm{Ab}$ & $0.082 \mathrm{Ac}$ & $0.166 \mathrm{ABb}$ & $0.573 \mathrm{Ba}$ \\
\hline Mixed & $0.166 \mathrm{Abc}$ & $0.087 \mathrm{Ac}$ & $0.249 \mathrm{Ab}$ & $0.500 \mathrm{Ba}$ \\
\hline \multicolumn{5}{|c|}{ APDW $(g)$} \\
\hline Control & $0.097 \mathrm{Aa}$ & $0.076 \mathrm{Aa}$ & $0.115 \mathrm{Aa}$ & $0.295 \mathrm{Ca}$ \\
\hline Rhizophagus clarum & $0.181 \mathrm{Abc}$ & $0.087 \mathrm{Ac}$ & $0.338 \mathrm{Ab}$ & $1.752 \mathrm{Aa}$ \\
\hline Gigaspora margarita & $0.168 \mathrm{Ab}$ & $0.079 \mathrm{Ab}$ & $0.234 \mathrm{Ab}$ & $0.851 \mathrm{Ba}$ \\
\hline Mixed & $0.171 \mathrm{Ab}$ & $0.086 \mathrm{Ab}$ & $0.308 \mathrm{Ab}$ & $1.039 \mathrm{Ba}$ \\
\hline \multicolumn{5}{|c|}{ DW (g) } \\
\hline Control & $0.228 \mathrm{Ab}$ & $0.152 \mathrm{Ab}$ & $0.230 \mathrm{Bb}$ & $0.599 \mathrm{Ca}$ \\
\hline Rhizophagus clarum & $0.337 \mathrm{Ac}$ & $0.163 \mathrm{Ac}$ & $0.586 \mathrm{Ab}$ & $2.628 \mathrm{Aa}$ \\
\hline Gigaspora margarita & $0.340 \mathrm{Abc}$ & $0.162 \mathrm{Ac}$ & $0.400 \mathrm{ABb}$ & $1.424 \mathrm{Ba}$ \\
\hline Mixed & $0.337 \mathrm{Ac}$ & 0.173 Ac & $0.556 \mathrm{Ab}$ & $1.539 \mathrm{Ba}$ \\
\hline \multicolumn{5}{|c|}{ DQI } \\
\hline Control & $0.07 \mathrm{Ab}$ & $0.04 \mathrm{Ab}$ & $0.06 \mathrm{Bb}$ & $0.19 \mathrm{Ca}$ \\
\hline Rhizophagus clarum & $0.09 \mathrm{Ab}$ & $0.04 \mathrm{Ac}$ & $0.14 \mathrm{Ab}$ & $0.39 \mathrm{Aa}$ \\
\hline Gigaspora margarita & $0.10 \mathrm{Ab}$ & $0.05 \mathrm{Ac}$ & $0.09 \mathrm{ABb}$ & $0.30 \mathrm{Ba}$ \\
\hline Mixed & $0.09 \mathrm{Abc}$ & $0.05 \mathrm{Ac}$ & $0.13 \mathrm{Ab}$ & $0.26 \mathrm{Ba}$ \\
\hline
\end{tabular}

Averages followed by the same capital letter in the column, or by the same small letter in the line, do not differ from each other according to Tukey's test at 5\%. Control: with no AMF inoculation; Mixed: G. margarita + R. clarum.

Leles et al. (2000) observed greater APDW and DWR in Eucalyptus spp. seedlings which had been sown in pressed blocks than in those sown in tubes. These authors attribute this to the greater volume of substrate present in a block than in a tube. This might explain the larger amounts of APDW, DWR and DW observed in this study in the Australian cedar seedlings which had been sown in pressed blocks, with or without AMF inoculation. Moreover, according to Freitas et al. (2005), seedlings planted in this kind of container can grow without their roots being confined, and with a morphological structure development closest to that found under natural conditions. These conditions lead to better root system development, with consequent greater absorption of water and nutrients, resulting in better development of the aerial part (LELES et al., 2000).

Lisboa et al. (2012) observed that the size of the container is a factor which affects the development of Australian cedar seedlings, highlighting the fact

Revista Árvore, Viçosa-MG, v.40, n.2, p.269-278, 2016 
Table 3 - Levels of macronutrients in the aerial parts of Australian cedar (Toona ciliata) 138 days after sowing, inoculated or not with AMF, in different kinds of containers.

Tabela 3 - Teores de macronutrientes na parte aérea de mudas de cedro australiano (Toona ciliata), 138 dias após a semeadura, inoculados ou não com FMAs, em diferentes recipientes.

\begin{tabular}{|c|c|c|c|c|c|}
\hline \multirow[t]{3}{*}{ AMF inoculation } & \multicolumn{5}{|c|}{ Containers } \\
\hline & Tube $130 \mathrm{~cm}^{3}$ & Tube $55 \mathrm{~cm}^{3}$ & Plastic Bag & Pressed Block & Averages \\
\hline & \multicolumn{5}{|c|}{ Nitrogen $\left(\mathrm{g} \mathrm{kg}^{-1}\right)$} \\
\hline Control & 8.35 & 7.02 & 10.14 & 12.17 & $9.42 \mathrm{~B}$ \\
\hline Rhizophagus clarum & 8.32 & 8.36 & 9.27 & 12.14 & $9.52 \mathrm{AB}$ \\
\hline Gigaspora margarita & 7.84 & 8.55 & 10.94 & 12.59 & $9.98 \mathrm{AB}$ \\
\hline Mixed & 8.86 & 8.45 & 10.81 & 12.70 & $10.21 \mathrm{~A}$ \\
\hline \multirow[t]{2}{*}{ Averages } & $8.10 \mathrm{c}$ & $8.34 \mathrm{c}$ & $10.29 \mathrm{~b}$ & $12.40 \mathrm{a}$ & - \\
\hline & \multicolumn{5}{|c|}{ Phosphorus $\left(\mathrm{g} \mathrm{kg}^{-1}\right)$} \\
\hline Control & $2.09 \mathrm{Bbc}$ & $1.79 \mathrm{Bc}$ & $2.45 \mathrm{Ab}$ & $3.16 \mathrm{Ca}$ & 2.37 \\
\hline Rhizophagus clarum & $2.55 \mathrm{Ab}$ & $2.31 \mathrm{Ab}$ & $2.60 \mathrm{Ab}$ & $3.41 \mathrm{Ca}$ & 2.72 \\
\hline Gigaspora margarita & $2.11 \mathrm{Bc}$ & $2.14 \mathrm{Abc}$ & $2.85 \mathrm{Ab}$ & $3.89 \mathrm{Ba}$ & 2.75 \\
\hline Mixed & $2.39 \mathrm{ABc}$ & $2.54 \mathrm{Abc}$ & $2.85 \mathrm{Ab}$ & $4.66 \mathrm{Aa}$ & 3.11 \\
\hline \multirow[t]{2}{*}{ Averages } & 2,28 & 2.19 & 2.69 & 3.78 & - \\
\hline & \multicolumn{5}{|c|}{ Potassium $\left(\mathrm{g} \mathrm{kg}^{-1}\right)$} \\
\hline Control & $15.82 \mathrm{Bc}$ & $15.87 \mathrm{ABc}$ & $19.29 \mathrm{BCb}$ & $23.01 \mathrm{Ba}$ & 18.50 \\
\hline Rhizophagus clarum & $17.78 \mathrm{ABb}$ & $14.63 \mathrm{Bc}$ & $18.75 \mathrm{Cb}$ & $26.01 \mathrm{Aa}$ & 19.30 \\
\hline Gigaspora margarita & $17.10 \mathrm{ABc}$ & $17.07 \mathrm{Ac}$ & $21.18 \mathrm{ABb}$ & $26.52 \mathrm{Aa}$ & 20.47 \\
\hline Mixed & $18.26 \mathrm{Ac}$ & $17.98 \mathrm{Ac}$ & $22.04 \mathrm{Ab}$ & $27.88 \mathrm{Aa}$ & 21.54 \\
\hline \multirow[t]{2}{*}{ Averages } & 17.24 & 16.39 & 20.32 & 25.87 & - \\
\hline & \multicolumn{5}{|c|}{ Calcium $\left(\mathrm{g} \mathrm{Kg}^{-1}\right)$} \\
\hline Control & $5.87 \mathrm{ABc}$ & $5.99 \mathrm{Bc}$ & $6.99 \mathrm{ABb}$ & $8.75 \mathrm{Aa}$ & 6.90 \\
\hline Rhizophagus clarum & $6.78 \mathrm{Aa}$ & $6.78 \mathrm{ABa}$ & $7.15 \mathrm{Aa}$ & $7.67 \mathrm{Ba}$ & 7.10 \\
\hline Gigaspora margarita & $5.77 \mathrm{Bb}$ & $6.71 \mathrm{ABb}$ & $6.04 \mathrm{Bb}$ & $8.90 \mathrm{Aa}$ & 6.86 \\
\hline Mixed & $6.69 \mathrm{ABb}$ & $7.11 \mathrm{Ab}$ & $7.58 \mathrm{Aab}$ & $8.25 \mathrm{ABa}$ & 7.41 \\
\hline \multirow[t]{2}{*}{ Averages } & 6.28 & 6.65 & 6.94 & 8.39 & - \\
\hline & \multicolumn{5}{|c|}{ Magnesium $\left(\mathrm{g} \mathrm{Kg}^{-1}\right)$} \\
\hline Control & 5.85 & 5.45 & 6.55 & 6.26 & 6.02 \\
\hline Rhizophagus clarum & 5.80 & 6.67 & 5.98 & 5.68 & 6.03 \\
\hline Gigaspora margarita & 5.67 & 5.90 & 5.75 & 6.68 & 6.00 \\
\hline Mixed & 5.79 & 5.94 & 6.87 & 6.68 & 6.32 \\
\hline Averages & 5.77 & 5.99 & 6.29 & 6.33 & - \\
\hline
\end{tabular}

Averages followed by the same capital letter in the column, or by the same small letter in the line, do not differ from each other according to Tukey's test at 5\%. Control: with no AMF inoculation; Mixed: G. margarita + R. clarum.

Table 4 - Percentage of mycorrhizal colonization in the roots of Australian cedar seedlings (Toona ciliata) 138 days after sowing, inoculated or not with AMF, in different kinds of containers.

Tabela 4 - Porcentagem de colonização micorrízica em raízes de mudas de cedro australiano (Toona ciliata) 138 dias após a semeadura, inoculados ou não com FMAs, em diferentes recipientes.

\begin{tabular}{lcccc}
\hline \multirow{2}{*}{ AMF inoculation } & \multicolumn{4}{c}{ Containers } \\
\cline { 2 - 5 } & Tube $130 \mathrm{~cm}^{3}$ & Tube $55 \mathrm{~cm}^{3}$ & Plastic Bag & Pressed Block \\
\cline { 2 - 5 } & & Mycorrhizal Colonization $(\%)$ \\
\hline Control & $42.50 \mathrm{Cab}$ & $37.50 \mathrm{Cab}$ & $27.50 \mathrm{Bb}$ & $50.00 \mathrm{Ba}$ \\
Rhizophagus clarum & $70.00 \mathrm{Ba}$ & $77.50 \mathrm{ABa}$ & $90.00 \mathrm{Aa}$ & $87.50 \mathrm{Aa}$ \\
Gigaspora margarita & $70.00 \mathrm{Bbc}$ & $57.50 \mathrm{BCc}$ & $95.00 \mathrm{Aa}$ & $90.00 \mathrm{Aab}$ \\
Mixed & $92.50 \mathrm{Aa}$ & $87.50 \mathrm{Aa}$ & $82.50 \mathrm{Aa}$ & $97.50 \mathrm{Aa}$ \\
\hline
\end{tabular}

Averages followed by the same capital letter in the column, or by the same small letter in the line, do not differ from each other according to Tukey's test at 5\%. Control: with no AMF inoculation; Mixed: G. margarita + R. clarum.

Revista Árvore, Viçosa-MG, v.40, n.2, p.269-278, 2016 
that of the seven characteristics evaluated, five (diameter, height, APDW, DWR and DW) showed the best performance when the seedlings were planted in larger tubes $\left(280 \mathrm{~cm}^{3}\right)$ rather than in smaller ones $\left(180 \mathrm{~cm}^{3}\right.$ and $115 \mathrm{~cm}^{3}$ ). The seedlings grown in tubes of 55 and $130 \mathrm{~cm}^{3}$, whether or not they had been inoculated with AMF, did not generally show any differences from each other with regard to the variables measured (diameter, height, APDW, DWR and DW), but they were significantly inferior to those grown in plastic bags and pressed blocks. Schiavo and Martins (2003) point out that, besides the smaller volume of the tubes, the rigid walls can cause physiological alterations in the seedlings, impeding the absorption process (of both water and nutrients).

Rocha et al. (2006) observed a greater increase in the development of native seedlings of $C$. fissilis (after 180 days) when they had been inoculated with Glomus clarum (now called Rhizophagus clarum) and G. margarita. This was also observed in the present study in relation to the Australian cedar seedlings grown in pressed blocks and plastic bags when inoculated with these species. Schiavo and Martins (2003) observed an increase of $41 \%$ in the APDW of Acacia mangium seedlings produced in pressed blocks when they were inoculated with Glomus macrocarpum, G. etunicatum and $E$. colombiana, in comparison with seedlings which had not been inoculated.

The Dickson Quality Index (DQI) scores, much lower in the seedlings grown in tubes of 130 and 55 $\mathrm{cm}^{3}$, in each inoculation treatment, could result from a possible restriction/limitation of nutrients and smaller retention of water in these containers (NEVES et al., 1990). According to Bernardino et al. (2005), the higher the index, the better the quality of the seedling will be. Lisboa et al. (2012) found DQI scores in Australian cedar seedlings 150 days after sowing of $0.98,1.29$ and 1.28, when grown in tubes of 115,180 and 280 $\mathrm{cm}^{3}$, respectively. These scores are much higher than those found in the present study. Caldeira et al.(2007) and Lisboa et al. (2012), believe that the DQI can vary according to the species, the way the seedlings are handled in the nursery, the kind and the proportion of substrate used, the size of the container and, above all, the age at which the seedlings are evaluated.

The symptoms of deficiency observed in seedlings produced in tubes $\left(55 \mathrm{~cm}^{3}\right.$ and $\left.130 \mathrm{~cm}^{3}\right)$, inoculated or not with AMF, are corroborated by the results found by Moretti et al. (2011) when studying the growth and the mineral nutrition of Australian cedar seedlings in situations when there was a deficiency of nutrients. These authors verified that that seedlings grown in soil which had a deficiency of $\mathrm{N}$, those which showed signs of deficiency, had an average level of $\mathrm{N}$ in the APDW of $8.7 \mathrm{~g} \mathrm{Kg}^{-1}$, that is, almost the same as that observed in the present study in seedlings grown in tubes of $55 \mathrm{~cm}^{3}$ and $130 \mathrm{~cm}^{3}$, inoculated or not with AMF.

The higher levels of $\mathrm{P}, \mathrm{K}$ and $\mathrm{Ca}$ in the aerial part of the seedlings grown in pressed blocks and inoculated with a mixture $R$. clarum + G. margarita could be related to a better root architecture without restrictions, since the roots can grow freely in this kind of container, resulting in a greater number of lateral roots (FREITAS et al., 2005). In addition, the combination of roots with AMF could give benefits to the host plant, leading to a better absorption of nutrients like P (BRESSAN et al., 2001; FREITAS et al., 2006), K (BRESSAN et al., 2001) and Ca (SCHIAVO et al., 2009).

There are several factors which could result in the mycorrhizae increasing the plants' absorption of nutrition. One of these is the fungal mycelium which increases the nutrient absorption area (GROVE et al., 1996), and which can increase the surface area exploited by the roots of the host plant by nine or ten centimeters (CAMEL et al., 1991). Schiavo and Martins (2003) observed that $A$. mangium seedlings which had been sown in tubes and inoculated with AMF had a greater increase in $\mathrm{P}$ than those in the treatment which received no inoculation.

The higher levels of mycorrhizal colonization in the seedlings inoculated with AMF, compared to those which had received no inoculation, and which had been grown in tubes of $55 \mathrm{~cm}^{3}$ and $130 \mathrm{~cm}^{3}$, were not reflected in increased seedling growth, in contrast to what was observed in the pressed block and plastic bag containers. According to Schiavo et al. (2010) the percentage of mycorrhizal colonization is not always a reliable characteristic for defining the effect that the species of fungus has on the growth and the nutrition of the host plant.

Rates of mycorrhizal colonization ranging between $57.5 \%$ and $97.5 \%$ were observed in seedlings inoculated with AMF, in different kinds of containers, rates which are far higher than those found by Rocha et al. (2006),

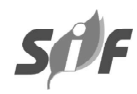

Revista Árvore, Viçosa-MG, v.40, n.2, p.269-278, 2016 
who observed average colonization rates of 20.8 and $9 \%$, in C. fissilis seedlings inoculated with $R$. clarum and $G$. margarita, respectively.

\section{CONCLUSIONS}

In Australian cedar seedlings, inoculation with Rhizophagus clarum or the mixed inoculant (Gigaspora margarita + Rhizophagus clarum) to seedlings grown in pressed blocks, resulted in the greatest seedling growth.

\section{REFERENCES}

AJALA, M.C.; AQUINO, N.F.; MALAVASI, U.C.; MALAVASI, M.M. Efeito do volume do recipiente na produção de mudas e no crescimento inicial de Jatropha curcas L. no Oeste Paranaense.

Semina: Ciências Agrárias, v.33, n.6, p.2039-2046, 2012.

ANGELINI, G.A.R.; SAGGIN JÚNIOR, O.J.; SILVA, E.M.R. Seleção de fungos micorrízicos arbusculares e ectomicorrízicos para simbioses eficientes com Acacia mangium willd. Semina: Ciências Agrárias, v.34, n.6, suplemento 1, p.3529-3542, 2013.

BARROSO, D.G.; CARNEIRO, J.G.A.; NOVAES, A.B.; LELES, P.S. Efeitos do recipiente sobre o desempenho pós-plantio de Eucalyptus camaldulensis e E. urophylla. Revista Árvore, v.24, n.3, p.291-296, 2000a.

BARROSO, D.G.; CARNEIRO, J.G.A.; LELES, P.S.S. Qualidade de mudas de Eucalyptus camaldulensis e E. urophylla produzidas em tubetes e em blocos prensados, com diferentes substratos. Floresta e Ambiente, v.7, n.1, p.238-250, 2000b.

BERNARDINO, D.C.S.; PAIVA, H.N.; NEVES, J.C.L.; GOMES, J.M.; MARQUES, V.B.

Crescimento e qualidade de mudas de Anadenanthera Macrocarpa (Benth.) Brenan em resposta à saturação por bases do substrato. Revista Árvore, v.29, n.6, p.863-870, 2005.

BRESSAN, W.; SIQUEIRA, J.O.; VASCONCELLOS, C.A.; PURCINO, A.A.C.Fungos micorrízicos e fósforo, no crescimento, nos teores de nutrientes e na produção do sorgo e soja consorciados.

Pesquisa Agropecuária Brasileira, v.36, p.250-260, 2001.

Revista Árvore, Viçosa-MG, v.40, n.2, p.269-278, 2016
CALDEIRA, M.V.W.; MARCOLIN, M.; MORAES, E.; SCHAADT, S.S. Influência do resíduo da indústria do algodão na formulação de substrato para produção de mudas de Schinus terebinthifolius Raddi, Archontophoenix alexandrae Wendl. et Drude e Archontophoenix cunninghamiana Wendl. et Drude. Ambiência, v.3, n.1, p.1-8, 2007.

CARMO, E.R. Produção de mudas de cedro australiano inoculadas com fungos micorrízicos arbusculares em diferentes recipientes. 2012. 59f. Dissertação (Mestrado em Produção Vegetal) - Universidade Estadual do Norte Fluminense Darcy Ribeiro, Campos dos Goytacazes, 2012.

CARnEIRO, J.G.A. Produção e controle de qualidade de mudas florestais. Curitiba: UFPR/FUPEF, 1995. 451p.

CARNEIRO, M.A.C.; SIQUEIRA, J.O.; DAVIDE, A.D. Fósforo e inoculação com fungos micorrízicos aubusculares no estabelecimento de mudas de embaúba (Cecropia pachystachua Trec). Pesquisa Agropecuária Tropical, v.34, n.3, p.119-125, 2004.

CAMEL, S.B.; REYES-SOLIS, M.G.; FERRERACERRATO, R.; FRANSON, R.L.; BROWN, M.S. \& BETHLENFALVAY, G.J. Growth of VA mycorrhizal myceluim through bulk soil. Soil Science Society of American Journal, v.55, p.389393, 1991 .

CUNNINGHAM, S.A.; FLOYD, R.B.; GRIFFITHS, M.W.; WYLIE, F.R. Patterns of host use by the shoot-borer Hypsipyla robusta (Pyralidae:Lepidoptera) comparing five Meliaceae tree species in Asia and Australia. Forest Ecology and Management, n.205, p.351357,2005 .

DANIEL, O.; VITORINO, A.C.T.; ALOVISI, A.A.; MAZZOCHIN, L.; TOKURA, A.M.; PINHEIRO, E.R.P.; SOUZA, E.F. Aplicação de fósforo em mudas de Acacia mangium WILLD. Revista Árvore, v.21, n.2, p.163-168, 1997.

FREITAS, T.A.S.; BARROSO, D.G.;CARNEIRO, J.G.A.; Penchel, R.M.; FIGUEIREDO, F.M.M.A. Mudas de eucalipto produzidas a partir de miniestacas em diferentes recipientes e 
substratos. Revista Árvore, v.30, n.4, p.519$528,2006$.

FREITAS, T.A.S.; BARROSO, D.G.; CARNEIRO, J.G.A.; PENCHEL, R.M.; LAMÔNICA, K.R.; FERREIRA, D.A. Desempenho radicular de mudas de eucalipto produzidas em diferentes recipientes e substratos. Revista Árvore, v.29, n.6, p.853861,2005

FREITAS, T.A.S.; BARROSO, D.G.; SOUZA, L.S.S.; CARNEIRO, J.G.A.; PAULINO, G.M. Produção de mudas de eucalipto com substratos para sistema de blocos. Revista Árvore, v.34, n. 5, p.761-770, 2010.

GIOVANETTI, M.; MOSSE, B. An evaluation of techniques for measuring vesicular-arbuscular mycorrhizal infection in roots. New

Phytologist., v.84, p.489-500, 1980.

GRACE, C.; STRIBLEY, P. A safer procedure for routine staining of vesicular-arbuscular mycorrhizal fungi. Mycological Research, v.95, n.10, p.1160-1162, 1991.

GROVE, T.S.; THOMSON, B.D.; MALAJCZUK, N. Nutritional physiology of eucalypts: uptake, distribution and utilization. In: ATTIWILL, P.M.; ADAMS, M.A. (Ed). Nutrition of Eucalypts. Melbourne: CSIRO Publishing, 1996. p.77-108.

HAHN, C.M.; NEVES, A.; OLIVEIRA, C.; AMARAL, E.M.; VALADARES, P.; MANARA, M. Recuperação florestal: da semente à muda. São Paulo: Secretaria do Meio ambiente para a conservação e Produção florestal do Estado de São Paulo, 2006. 144p.

JACKSON, C.M. Soil chemical analysis Englewood Cliffs: Prentice-Hall, 1965.

KALIL FILHO, A.N.; WENDLING, I. Produção de mudas de cedro australiano. Colombo: 2012.5p. (Comunicado técnico)

KELLER, L.; LELES, P.S.S.; OLIVEIRA NETO, S.N.; COUTINHO, R.P.; NASCIMENTO, D.F. Sistema de blocos prensados para produção de mudas de três espécies arbóreas nativas. Revista Árvore v.33, n.2, p.305-314, 2009.
LELES, P.S.S.; CARNEIRO, J.G.A.; BARROSO, D.G.; MORGADO, I.F. Qualidade de mudas de Eucalyptus spp. produzidas em blocos prensados e em tubetes. Revista Árvore, v.24, n.1, p.13-20, 2000.

LIMA, F.S.; SOUSA, C.S. Crescimento e nutrição de mudas de clones de eucalipto inoculadas com fungos micorrízicos. Pesquisa Agropecuária Tropical, v.44, n.2, p.110$118,2014$.

LISBOA, A.C.; LELES, P.S.S.; OLIVEIRA NETO, S.N.; CASTRO, D.N.; ABREU, A.H.M. Efeito do volume de tubetes na produção de mudas de Calophyllum brasiliense e Toona ciliata.

Revista Árvore, v.36, n.4, p.603-609, 2012.

MALAVOLTA, E.; VITTI, G.C.; OLIVEIRA, S.A. Avaliação do estado nutricional das plantas: princípios e aplicações. 2.ed. Piracicaba: POTAFOS, 1997. 319p.

MORETTI, B.S.; FURTINI NETO, A.E.; PINTO, S.I.C.; FURTINI, I.V.; MAGALHÃES, C.A.S.

Crescimento e nutrição mineral de mudas de cedro australiano (Toona ciliata) sob omissão de nutrientes. Cerne, v. 17, n.4, p.453-463, 2011.

MURAKAMI, C.H.G. Cedro Australiano: valorização de espécies nobres. Boletim Florestal, v. 7, n.2, p.1-6, 2008.

NEVES, J.C.L.; GOMES, J.M.; NOVAIS, R.F. Fertilização mineral de mudas de eucalipto. In: BARROS, N.F.; NOVAIS, R.F. (Ed.) Relação solo-eucalipto. Viçosa, MG: Folha de Viçosa, 1990. p.99-126.

PINHEIRO, A.L.; LANI, L.L.; COUTO, L. Cultura do cedro australiano para produção de madeira serrada. Viçosa, MG: UFV, 2003. 42p.

ROCHA, F.S.; SAGGIN JÚNIOR, O.J., SILVA, E.M.R.; LIMA, W.L. Dependência e resposta de mudas de cedro a fungos micorrízicos arbusculares. Pesquisa Agropecuária Brasileira, v.41, n.1, p.77-84, 2006.

SCHIAVO, J.A.; MARTINS, M.A.; RODRIGUES, L.A. Avaliação nutricional de mudas de Acacia

Revista Árvore, Viçosa-MG, v.40, n.2, p.269-278, 2016 
mangium, Sesbania virgata e Eucalyptus camaldulensis inoculadas com fungos micorrízicos, em casa de vegetação e em cava de extração de argila. Acta Scientiarum Agronomy, v.31, n.4, p.701-707, 2009.

SCHIAVO, J.A.; MARTINS, M.A. Produção de mudas de acácia colonizadas com micorrizas e rizóbio em diferentes recipientes. Pesquisa Agropecuária Brasileira, v. 38, n.2, p.173-178, 2003.

SOUZA, J.C.A.V.; BARROSO, D.G.; CARNEIRO, J.G.A.; TEIXEIRA, S.L.;

BALBINOT, E. Propagação vegetativa de cedro-austaliano (Toona ciliata $\mathrm{M}$. Roemer) por miniestaquia. Revista Árvore, v.33, n.2, p.205-213, 2009.
WORLD AGROFORESTRY CENTRE-WAC. AgroforestryTree Database - A Tree Species Reference and Selection Guide in: http:// www.worldagroforestrycentre.org/sea/Products/ AFDbases/af/asp/SpeciesInfo.asp?SpID. Acessado em: 25/08/2012.

ZANI FILHO, J. Evolução tecnológica de viveiros florestais. In: SIMPÓSIO IPEF - A reengenharia e seus impactos no desenvolvimento científico e tecnológico do setor florestal. Piracicaba: 1996. Anais IPEF, v.2, p.15-23, 1996.

ZONTA, E.P.; MACHADO, A.A.; SILVEIRA

JÚNIOR, P. Sistema de análises estatísticas para microcomputadores (SANEST). Pelotas: Universidade Federal de Pelotas, 1984. 151p. 